\title{
Performance Degradation of a 43 MW Class Gas Turbine Engine in Kuwait Climate
}

\author{
${ }^{1}$ Ali Dinc, ${ }^{2}$ Rani Taher, ${ }^{3}$ Javad Farrokhi Derakhshandeh, ${ }^{4}$ Mohamed Fayed, ${ }^{5}$ Ibrahim Elbadawy, ${ }^{6}$ Yousef Gharbia \\ ${ }^{1,2,3,4,5,6}$ College of Engineering and Technology, American University of the Middle East, Kuwait
}

\begin{abstract}
In this study, the performance estimations of a land-based gas turbine engine were done considering hot climate regions and therefore deviations from standard day $15^{\circ} \mathrm{C}$ conditions. In hot climate countries like Kuwait, ambient air temperature often reaches and exceeds $50^{\circ} \mathrm{C}$, which makes dramatic performance reductions for the gas turbine engines. The gas turbine performance output parameters were calculated in a range of ambient air temperature $\left(15^{\circ} \mathrm{C}-55^{\circ} \mathrm{C}\right)$. Results show that for a $43 \mathrm{MW}$ class gas turbine engine at $55^{\circ} \mathrm{C}$ ambient condition, the shaft power output decreases $21.3 \%$ and power specific fuel consumption (PSFC) increases 9.31\%. Thermal efficiency also decreases from $\mathbf{4 1 . 9 0 \%}$ standard day value to $38.34 \%$.
\end{abstract}

Keywords: Gas turbine engine; Cycle analysis, Performance, Hot climate, Efficiency, Ambient temperature.

\section{Nomenclature}

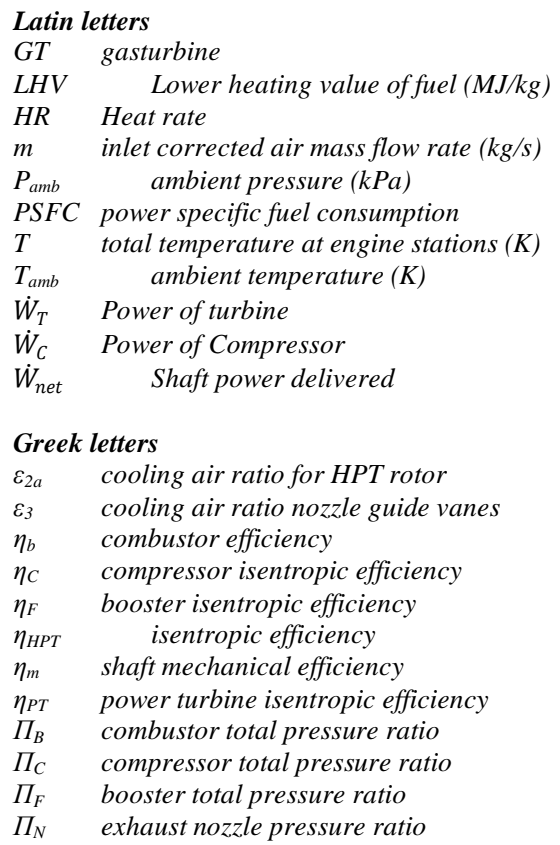

\section{INTRODUCTION}

It is well understood that the ambient temperature plays an important role on the performance of a gas turbine [1]. The higher the ambient temperature, the density of the intake air decreases, resulting in reduction of the mass flow and increasing the compressor specific work [2]. Ambient temperature not only impacts on several critical parameters such as mass flow and efficiency of the gas turbine system [3], [4] but also assists in saving electricity, which is produced with its challenges [5]-[7].

A numerically study was performed on the effects of several operating parameters including, the turbine inlet temperature, the cycle pressure ratio and the relative humidity of the ambient on the performance of a gas turbine considering the first and second law of thermodynamics simultaneously [8]. This simultaneous analysis assisted authors to optimize the efficiency of the gas turbine cycle. It was observed that the maximum useful produced work during a cycle was significantly affected by the turbine inlet temperature and compressor pressure ratio. Though the energy destruction of gas turbine process is not influenced by ambient relative humidity at all. It was also found that by increasing the turbine inlet temperature from $1000 \mathrm{~K}$ to $2200 \mathrm{~K}$, the network output linearly increases from $\approx 32 \%$ to $\approx 61 \%$.

Another study showed the effects of ambient temperature on the performance of the land-based gas turbine [9]. It was shown that the compressor inlet temperature plays a significant role on the performance of the gas turbine. Authors employed evaporative cooling systems in three large cities in Iran with different climate conditions. It was shown that by using an evaporative cooler system leads to a higher generated power output as compared with power plant without a cooler system. The author improved the efficiency up to $14.5 \%$. It was also demonstrated that employing an evaporative cooling system has a better performance in a climate with a high temperature, less humidity and more hot hours per day as compared with other conditions.

Review of literature demonstrated that the gas turbine performance is significantly depends on environmental conditions, in particular, the inlet temperature of the air. A study was about evaluating two cooling systems, including evaporative (cheap with lower benefits) and absorbing (expensive with significant advantage) systems [10]. Authors showed that during summer months by reducing the compressor inlet temperature not only the performance of the 
ISSN (online): 2581-3048

gas turbine system increases but also it is very cost effective. Although the initial cost of the absorption cooling system was higher as compared with evaporative cooling system, the author showed that the generated power output could increase by $18 \%$ in warmest months during the year by this system. Therefore, the power demand for compressing the inlet air increases. Several investigations have been conducted to enhance the performance of gas turbine through different cooling methods among which steam injection (STI) that use the heat recovery steam generator (HRSG), inlet air cooling (IAC) where different techniques has been used to achieve cooling at the inlet compressor air (fogging, evaporative coolers, absorption chiller etc.) in addition to evaporation cycle and combined cycle methods [11].

Due to the significant influence of the air inlet temperature and humidity on the gas turbine performance, four cooling systems were studied [12] comprising, evaporative chiller, a single absorption cooling system, mechanical chiller and fogging cooling system. Authors investigated the effects of several parameters such as power output, fuel consumption, the efficiency of the cycle and condensable water[12]. Similar to previous study [10], the authors confirmed that the absorption cooling system has maximum influence on the power output and efficiency with $37.3 \%$ and $31.5 \%$, respectively [12] which was followed by those factors of mechanical chiller with $24.3 \%$ and $18.8 \%$, respectively. On the other hand, the evaporative cooling had a minimum improvement on power output with $8.7 \%$ and efficiency by up to $3.3 \%$. The fogging system showed slightly higher improvement for power (9.5\%) and efficiency (3.5\%), respectively as compared with evaporative cooling system. It was also demonstrated that the mechanical chiller and absorption cooling system are much less dependent on humidity as compared with evaporative chillers and fogging cooling system [12].

Another research compared the effects of different inlet temperature and humidity using fogging system and absorption chiller on an actual power plant of Khangiran in Iran to enhance the performance of the gas turbine [13]. The outcomes were technically and economically compared [13]. Similar results were found by authors as compared with other scholars [10], [12]; authors confirmed that employing absorption chiller provides a better performance for the cycle and the efficiency improvement is approximately $5 \%$ which was higher than that of fogging system with $3 \%$.

Another method was proposed for cooling inlet temperature of the gas turbine[14]. The authors suggested that by crossing a flow gas to gas heat exchanger the ambient air temperature reduces. This leads to produce a low compressor inlet temperature. It was showed that by dropping the inlet temperature up to $25 \mathrm{~K}$, the performance of Khangiran gas refinery can be improved up to $3.5 \%$ during relatively warm months (approximately nine months)[14].

Performance degradation due to ambient conditions was studied and it is inevitable not only land-based gas turbines but also for the gas turbine aircraft engines such as turboprop, turbo-shaft, turbofan engines [15]-[21].

\section{MATERIALS AND METHODS}

Figure 1 illustrates a simple sketch of a standard gas turbine power plant. The gas turbine power plant consists of an air intake, compressor, combustion chamber, turbine, and exhaust. In this work, the performance of the gas turbine was evaluated at different ambient temperatures $\left(15^{\circ} \mathrm{C}-55^{\circ} \mathrm{C}\right)$. Considering hot climate regions. The working fluid passing through the compressor is the air, and it assumed to be an ideal gas, while in the turbine the working fluid are the flue gases.

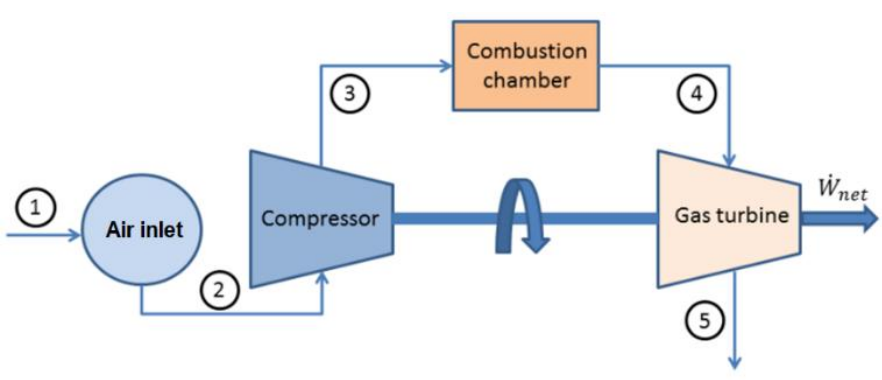

Figure 1: Schematic of the gas turbine

$$
\begin{gathered}
\dot{Q}_{\text {in }}=\dot{m}_{a} \cdot C_{p g, a v g} \cdot\left(T_{4}-T_{3}\right) \\
\dot{m}_{f}=\frac{\dot{Q}_{\text {in }}{ }_{L H V}}{\eta_{\text {Combustor }}} \\
\dot{W}_{C}=\dot{m}_{a} \cdot C_{p a, a v g} \cdot\left(T_{3}-T_{2}\right) \\
\dot{W}_{T}=\dot{m}_{T} \cdot C_{p g, a v g} \cdot\left(T_{5}-T_{4}\right) \\
\dot{m}_{T}=\dot{m}_{a}+\dot{m}_{f} \\
\dot{W}_{n e t}=\dot{W}_{T}-\dot{W}_{C} \\
P S F C=\frac{3600 \cdot \dot{m}_{f}}{\dot{W}_{\text {net }}} \\
H R=S F C \cdot L H V \\
\eta_{t h}=\frac{3600}{P S F C \cdot L H V}
\end{gathered}
$$

Above equations were used to estimate the performance of a gas turbine engine, with a detailed cycle analysis. The cycle analysis covers thermodynamic calculations of all main components shown in Figure 1. The cycle analysis results 
ISSN (online): 2581-3048

Volume 5, Issue 4, pp 108-113, April-2021

https://doi.org/10.47001/IRJIET/2021.504016

include the total pressure and temperature values at every engine station, engine performance values such as shaft power output, power specific fuel consumption (PSFC), heat rate and fuel flow rate [22].

In this study, cycle analysis of a gas turbine was conducted for 43 MW class similar to General Electric LM6000 gas turbine engine [23].

A set of input values were assumed and used in the cycle analysis calculations, which are given in Table 1. Shaft power (MW) and heat rate $(\mathrm{kJ} / \mathrm{kWh})$ are considered and compared with manufacturer`s data extracted from reference[23]in Table 2 . The results show that the numerical results are well matched with published data with less than $0.2 \%$ deviation for both selected parameters [24].

Table 1: Assumed design input parameters for baseline gas turbine engine

\begin{tabular}{lll}
\hline $\begin{array}{l}\text { Engine } \\
\text { parameter }\end{array}$ & Definition & $\begin{array}{l}\text { Assumed } \\
\text { Value }\end{array}$ \\
\hline $\mathrm{T}_{4}$ & total temperature at turbine entry (K) & 1500 \\
$\Pi_{\mathrm{B}}$ & burner/combustor total pressure ratio & 0.95 \\
$\Pi_{\mathrm{C}}$ & compressor total pressure ratio & 12.2 \\
$\Pi_{\mathrm{F}}$ & booster total pressure ratio & 2.4 \\
$\Pi_{\mathrm{N}}$ & exhaust nozzle pressure ratio & 1.1 \\
$\eta_{\mathrm{b}}$ & combustor efficiency & 0.9995 \\
$\eta_{\mathrm{C}}$ & compressor isentropic efficiency & 0.90 \\
$\eta_{\mathrm{F}}$ & booster isentropic efficiency & 0.90 \\
$\eta_{\mathrm{HPT}}$ & high pressure turbine isentropic & 0.88 \\
& efficiency & \\
$\eta_{\mathrm{m}}$ & shaft mechanical efficiency & 0.999 \\
$\eta_{\mathrm{PT}}$ & power turbine isentropic efficiency & 0.91 \\
$\varepsilon_{2 \mathrm{a}}$ & cooling air ratio for high pressure & 0.03 \\
& turbine rotor & \\
$\varepsilon_{3}$ & cooling air ratio nozzle guide vanes & 0.03 \\
$\mathrm{~T}_{\mathrm{amb}}$ & ambient temperature (K) & 288.15 \\
$\mathrm{P}_{\mathrm{amb}}$ & ambient pressure (kPa) & 101.325 \\
$\mathrm{~m}$ & inlet corrected air mass flow rate (kg/s) & 119 \\
$\mathrm{LHV}$ & Fuel heating value (natural gas) & 44.194 \\
& (MJ/kg) & \\
\hline
\end{tabular}

Table 2: Comparison of main output performance parameters for baseline engine

\begin{tabular}{lccc}
\hline Parameter & $\begin{array}{c}\text { Literature } \\
\text { Data* }^{*}\end{array}$ & $\begin{array}{c}\text { Calculated Value for } \\
\text { Baseline Engine }\end{array}$ & $\begin{array}{c}\text { Deviation } \\
(\%)\end{array}$ \\
\hline $\begin{array}{l}\text { Shaft power } \\
(\mathrm{MW})\end{array}$ & 43,284 & 43,370 & $0.19 \%$ \\
$\begin{array}{l}\text { Heat rate } \\
(\mathrm{kJ} / \mathrm{kWh})\end{array}$ & 8,581 & 8,591 & $0.12 \%$ \\
\hline
\end{tabular}

*Source: [23]

\section{RESULTS AND DISCUSSION}

In this section, the effects of ambient temperature on the output power, heat rate, thermal efficiency, fuel mass flow rate and power specific fuel consumption (PSFC) are studied.

\subsection{Influence of ambient air temperature on heat rate and power output}

The correlation of ambient temperature and power output is shown in Figure 2. It is found that once the $T_{a m b}$ is at standard day value which is $15^{\circ} \mathrm{C}$, the nominal power output is achieved. It is also observed that during the hot months once the $\mathrm{T}_{\mathrm{amb}}$ reaches to $55{ }^{\circ} \mathrm{C}$ (in Kuwait) the power output significantly drops by $21.3 \%$ (as shown in Figure 4) and reaches to $34,147(\mathrm{~kW})$.

Figure 3 also show that the amount of heat rate of the gas turbine increases up to $9.3 \%$ once the $\mathrm{T}_{\mathrm{amb}}$ increases from $15^{\circ} \mathrm{C}$ to $55^{\circ} \mathrm{C}$

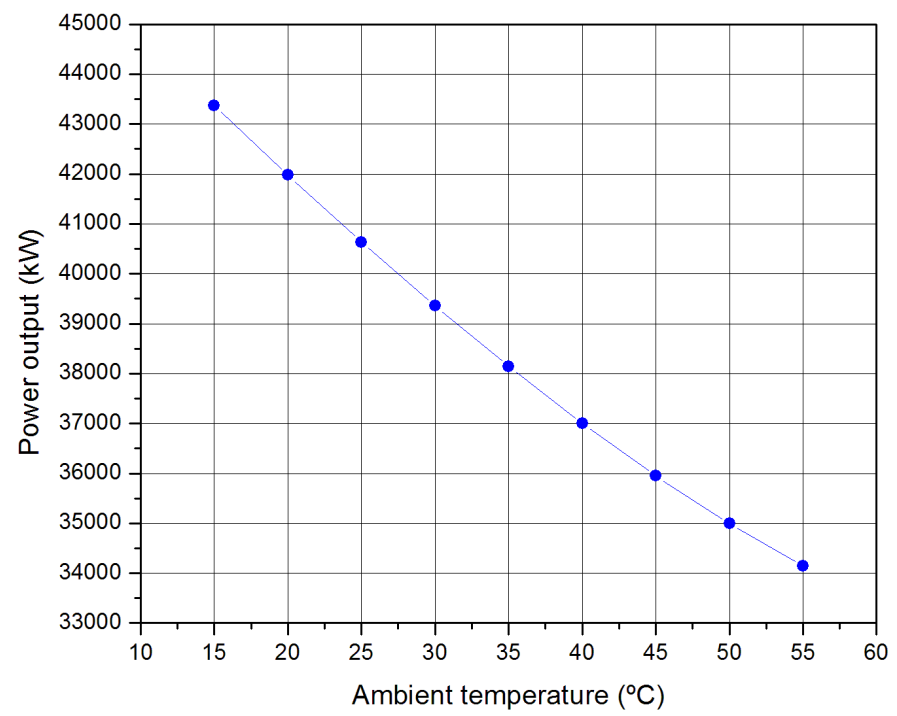

Figure 2: Effect of ambient temperature on the gas turbine power output

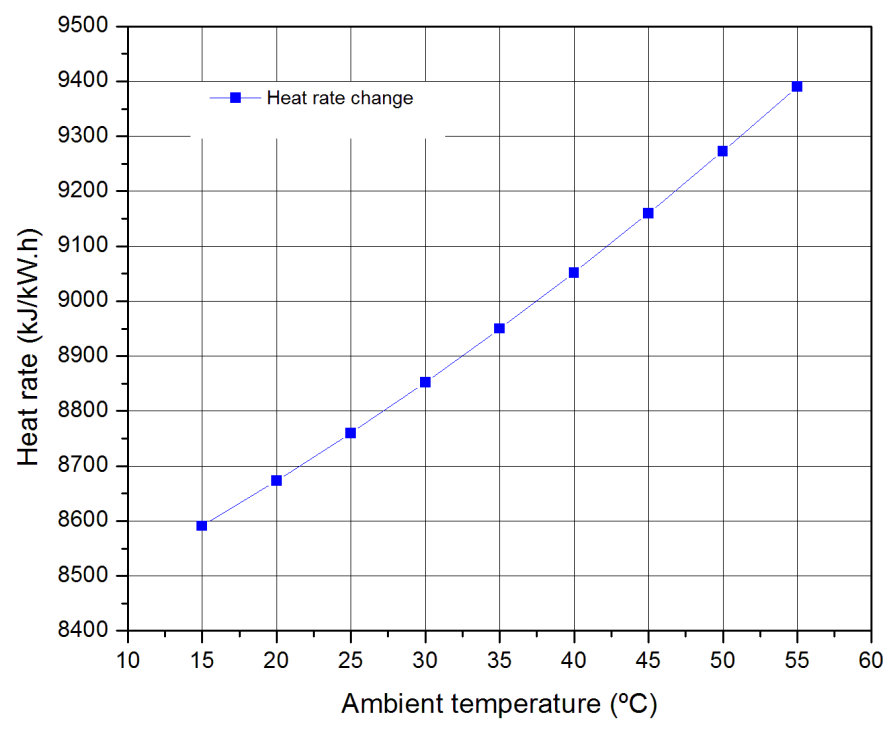

Figure 3: Effect of ambient temperature on the heat rate 
ISSN (online): 2581-3048

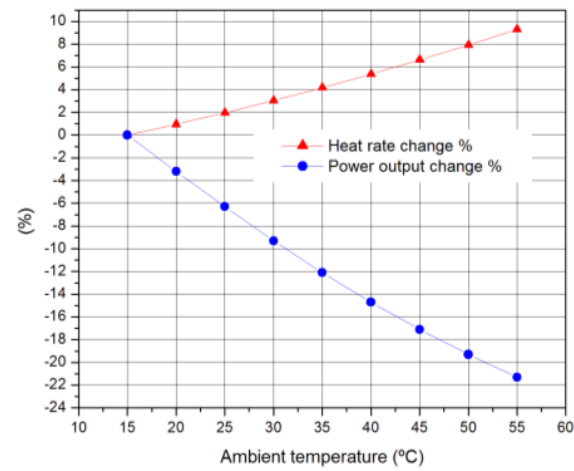

Figure 4: percentage change in gas turbine heat rate and power output with ambient temperature change

\subsection{Influence of ambient air temperature on thermal efficiency}

In this paper, the thermal efficiency of the system is studied and the effects of $\mathrm{T}_{\mathrm{amb}}$ on the thermal efficiency are shown on Figure 5. As expected, once the temperature of ambient changes from $15{ }^{\circ} \mathrm{C}$ to $55^{\circ} \mathrm{C}$, the results reveal that thermal efficiency decreases from $41.9 \%$ to $38.34 \%$. Therefore, the thermal efficiency of the system by $3.56 \%$ reduction provides a worse performance as compared with a lower $\mathrm{T}_{\mathrm{amb}}$.

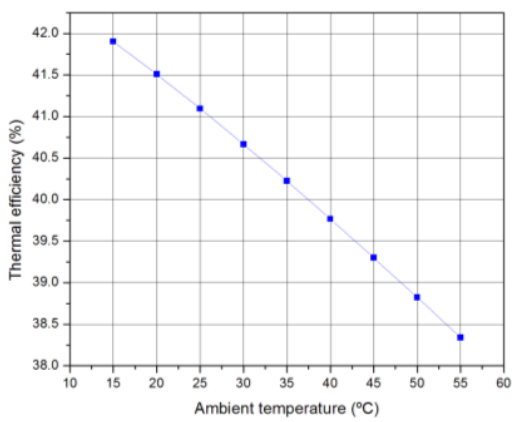

Figure 5: Ambient temperature variations effect on gas turbine thermal efficiency
https://doi.org/10.47001/IRJIET/2021.504016

3.3 Influence of ambient air temperature variation on fuel rate and power specific fuel consumption

The variations of the fuel mass flow rate $(\mathrm{kg} / \mathrm{s})$ and power specific fuel consumption $\left(\mathrm{kg} / \mathrm{kW}\right.$. h) as a function of $\mathrm{T}_{\mathrm{amb}}$ were evaluated and the results are shown in Figures 6, 7 and 8. It is found that fuel mass flow rate decreases from 2.342 to $2.015(\mathrm{~kg} / \mathrm{s})$ equivalent with $14 \%$ reduction by changing the $\mathrm{T}_{\text {amb }}$ from $15^{\circ} \mathrm{C}$ to $55^{\circ} \mathrm{C}$ (see Figures6 and 8). However, this is not a gain or fuel saving because this happens due to the decreased air mass flow rate through the engine at hot ambient conditions. In fact, it is seen that power specific fuel consumption, which measures the weight flow rate of fuel increases $9.3 \%$ due to this $\mathrm{T}_{\mathrm{amb}}$ increment as shown in Figure7.

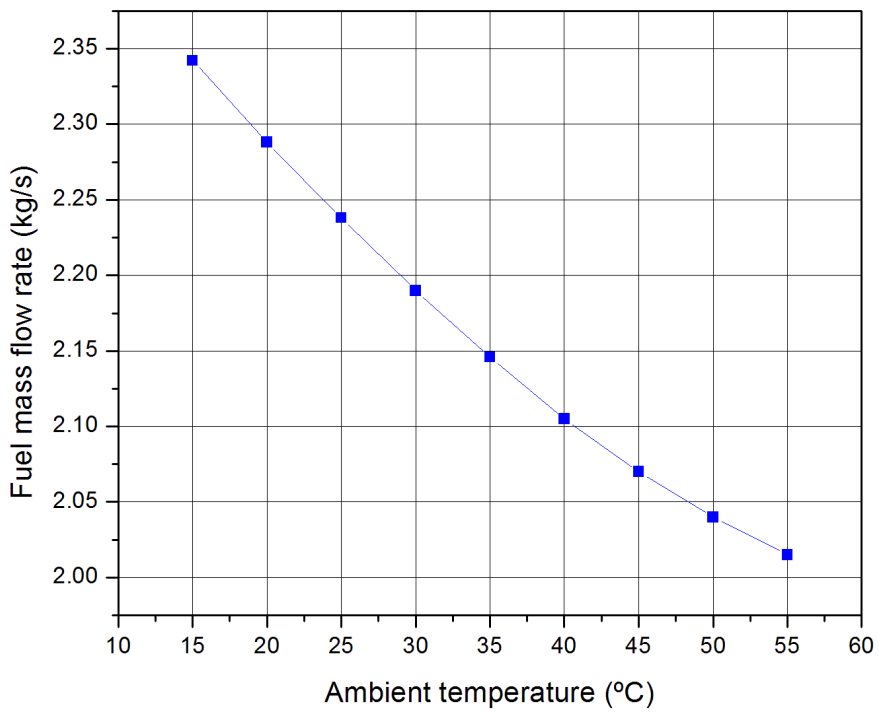

Figure 6: Gas turbine fuel mass flow rate changes with ambient temperatures

Table 3: Effect of inlet temperature on the engine performance

\begin{tabular}{cccccccccc}
\hline $\begin{array}{c}\text { Inlet Temp } \\
{ }^{\circ} \mathrm{C}\end{array}$ & $\begin{array}{c}\text { Fuel } \\
\text { flow } \\
(\mathrm{kg} / \mathrm{s})\end{array}$ & $\begin{array}{c}\text { Change } \\
\text { from } \\
15^{\circ} \mathrm{C}\end{array}$ & $\begin{array}{c}\mathrm{HR} \\
(\mathrm{kJ} / \mathrm{kWh}\end{array}$ & $\begin{array}{c}\text { Change } \\
\text { from } \\
15^{\circ} \mathrm{C}\end{array}$ & $\begin{array}{c}\dot{W}_{\text {net }} \\
(\mathrm{kW})\end{array}$ & $\begin{array}{c}\text { Change } \\
\text { from } \\
15^{\circ} \mathrm{C}\end{array}$ & $\begin{array}{c}\text { PSFC } \\
(\mathrm{kg} / \mathrm{kWh})\end{array}$ & $\begin{array}{c}\text { Change } \\
\text { from } 15^{\circ} \\
\mathrm{C}\end{array}$ & $\begin{array}{c}\text { Thermal } \\
\text { Efficiency }\end{array}$ \\
\hline $15^{*}$ & 2.342 & $0.0 \%$ & 8591 & $0.00 \%$ & 43370 & $0.0 \%$ & 0.1944 & $0.00 \%$ & $41.90 \%$ \\
20 & 2.288 & $-2.3 \%$ & 8673 & $0.95 \%$ & 41976 & $-3.2 \%$ & 0.1962 & $0.93 \%$ & $41.51 \%$ \\
25 & 2.238 & $-4.5 \%$ & 8760 & $1.97 \%$ & 40638 & $-6.3 \%$ & 0.1982 & $1.95 \%$ & $41.10 \%$ \\
\hline 30 & 2.190 & $-6.5 \%$ & 8852 & $3.04 \%$ & 39358 & $-9.3 \%$ & 0.2003 & $3.03 \%$ & $40.67 \%$ \\
35 & 2.146 & $-8.4 \%$ & 8950 & $4.17 \%$ & 38143 & $-12.1 \%$ & 0.2025 & $4.17 \%$ & $40.22 \%$ \\
40 & 2.105 & $-10.1 \%$ & 9052 & $5.37 \%$ & 37004 & $-14.7 \%$ & 0.2048 & $5.35 \%$ & $39.77 \%$ \\
\hline 45 & 2.070 & $-11.6 \%$ & 9160 & $6.62 \%$ & 35950 & $-17.1 \%$ & 0.2073 & $6.64 \%$ & $39.30 \%$ \\
50 & 2.040 & $-12.9 \%$ & 9273 & $7.93 \%$ & 34993 & $-19.3 \%$ & 0.2098 & $7.92 \%$ & $38.82 \%$ \\
55 & 2.015 & $-13.9 \%$ & 9390 & $9.30 \%$ & 34147 & $-21.3 \%$ & 0.2125 & $9.31 \%$ & $38.34 \%$ \\
\hline
\end{tabular}


ISSN (online): 2581-3048

Volume 5, Issue 4, pp 108-113, April-2021 https://doi.org/10.47001/IRJIET/2021.504016

Table 2 shows the effects of $\mathrm{T}_{\mathrm{amb}}$ on main features and indicators of the gas turbine such as mass flow rate, heat rate, power, PSFC and efficiency. The numerical results show that the efficiency of the gas turbine reduces approximately from 41 to $38 \%$ once the $\mathrm{T}_{\mathrm{amb}}$ gradually increases from $15^{\circ} \mathrm{C}$ to 55 ${ }^{\circ} \mathrm{C}$.

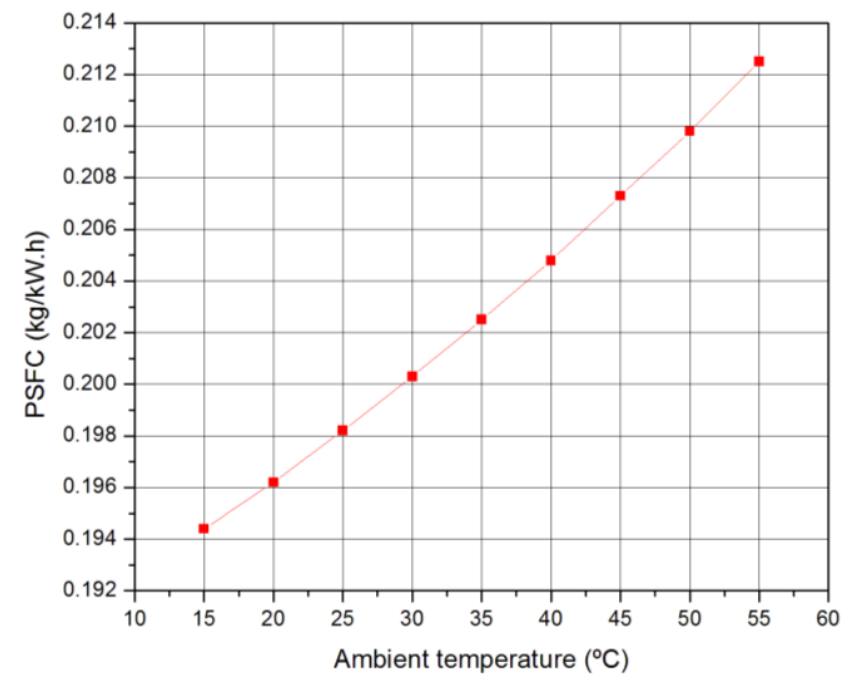

Figure 7: Gas turbine power specific fuel consumption changes with ambient temperatures

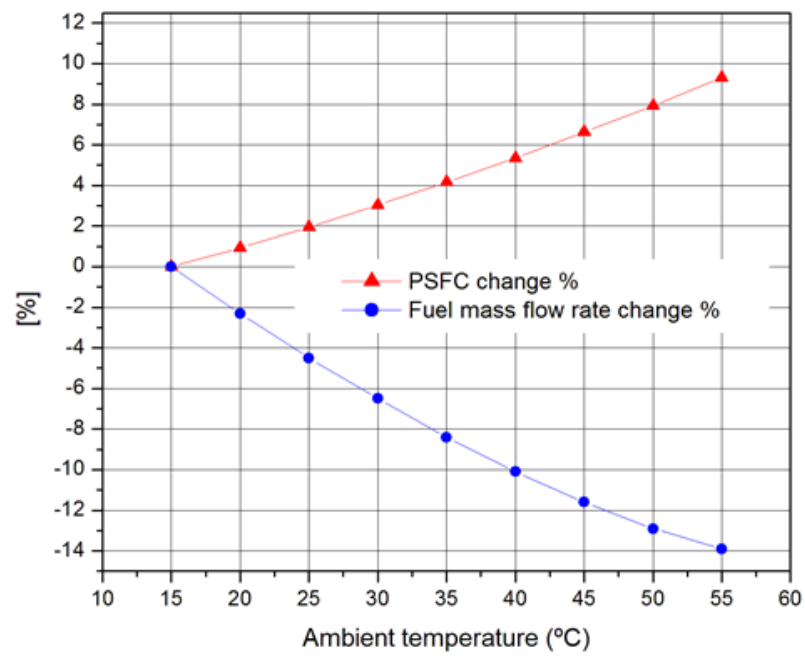

Figure 8: percentage change in gas turbine heat rate and power output with ambient temperature change

\section{CONCLUSIONS}

The effects of ambient temperature $\left(\mathrm{T}_{\mathrm{amb}}\right)$ and degradation on gas turbine engine performance was studied in this paper. A comprehensive comparison is performed on a few indicators such as output power, heat rate, thermal efficiency, fuel mass flow rate and power specific fuel consumption (PSFC) for an interval of the $\mathrm{T}_{\mathrm{amb}}$ between $15^{\circ} \mathrm{C}$ to $55^{\circ} \mathrm{C}$. The numerical results support following conclusions once the $\mathrm{T}_{\mathrm{amb}}$ changes from $15^{\circ} \mathrm{C}$ to $55^{\circ} \mathrm{C}$ :
- It is found that during the hot months, the power output significantly drops by $21.3 \%$.

- Power specific fuel consumption (PSFC) increases $9.31 \%$.

- The amount of heat rate of the gas turbine increases up to $9.3 \%$.

- The thermal efficiency of the turbine shows $3.56 \%$ reduction from $41.90 \%$ standard day value to $38.34 \%$.

- Lastly, it is observed that fuel mass flow rate can decrease from 2.34 to $2.01(\mathrm{~kg} / \mathrm{s})$ equivalent with $14 \%$ reduction due to decreased air mass flow rate through the engine at higher inlet temperatures.

\section{REFERENCES}

[1] M. B. Hashmi, M. A. A. Majid, and T. A. Lemma, "Combined effect of inlet air cooling and fouling on performance of variable geometry industrial gas turbines," Alexandria Eng. J., vol. 59, no. 3, pp. 1811 1821, Jun. 2020, doi: 10.1016/j.aej.2020.04.050.

[2] T. K. Ibrahim, M. M. Rahman, and A. N. Abdalla, "Optimum gas turbine configuration for improving the performance of combined cycle power plant," Procedia Eng., vol. 15, no. October 2015, pp. 42164223, 2011, doi: 10.1016/j.proeng.2011.08.791.

[3] B. K. Kurz R., "Degradation in gas turbine systems," J. Eng. Gas Turbines Power, vol. 123, no. 1, pp. 7077, 2001, doi: 10.1115/1.1340629.

[4] H. H. Erdem and S. H. Sevilgen, "Case study: Effect of ambient temperature on the electricity production and fuel consumption of a simple cycle gas turbine in Turkey," Appl. Therm. Eng., vol. 26, no. 2-3, pp. 320-326, Feb. 2006, doi: 10.1016/j.applthermaleng.2005.08.002.

[5] M. Esen and T. Yuksel, "Experimental evaluation of using various renewable energy sources for heating a greenhouse," Energy Build., vol. 65, pp. 340-351, Oct. 2013, doi: 10.1016/j.enbuild.2013.06.018.

[6] M. Hadipour, J. F. Derakhshandeh, M. A. Shiran, and R. Rezaei, "Automatic washing system of LED street lighting via Internet of Things," Internet of Things, vol. 1-2, pp. 74-80, Sep. 2018, doi: 10.1016/j.iot.2018.08.006.

[7] M. Hadipour, J. F. Derakhshandeh, and M. A. Shiran, "An experimental setup of multi-intelligent control system (MICS) of water management using the Internet of Things (IoT)," ISA Trans., vol. 96, pp. 309-326, Jan. 2020, doi: 10.1016/j.isatra.2019.06.026.

[8] A. Khaliq and K. Choudhary, "Thermodynamic performance assessment of an indirect intercooled reheat regenerative gas turbine cycle with inlet air cooling and evaporative aftercooling of the 
ISSN (online): 2581-3048

compressor discharge," Int. J. Energy Res., vol. 30, no. 15, pp. 1295-1312, Dec. 2006, doi: 10.1002/er.1221.

[9] M. Ameri, H. R. Shahbazian, and M. Nabizadeh, "Comparison of evaporative inlet air cooling systems to enhance the gas turbine generated power," Int. J. Energy Res., vol. 31, no. 15, pp. 1483-1503, Dec. 2007, doi: 10.1002/er.1315.

[10] M. De Lucia, C. Lanfranchi, and V. Boggio, "Benefits of Compressor Inlet Air Cooling for Gas Turbine Cogeneration Plants," J. Eng. Gas Turbines Power, vol. 118, no. 3, pp. 598-603, Jul. 1996, doi: 10.1115/1.2816690.

[11] F. J. Wang and J. S. Chiou, "Integration of steam injection and inlet air cooling for a gas turbine generation system," Energy Convers. Manag., vol. 45, no. 1, pp. 15-26, Jan. 2004, doi: 10.1016/S01968904(03)00125-0.

[12] Y. S. H. Najjar and Y. M. A. Al-Zoghool, "Sustainable energy development in power generation by using green inlet-air cooling technologies with gas turbine engines," J. Eng. Thermophys., vol. 24, no. 2, pp. 181-204, Apr. 2015, doi: 10.1134/S1810232815020083.

[13] M. Deymi-Dashtebayaz, M. Farzaneh-Gord, A. Arabkoohsar, A. B. Khoshnevis, and H. Akeififar, "Improving Khangiran gas turbine efficiency by two standard and one novel inlet air cooling method," J. Brazilian Soc. Mech. Sci. Eng., vol. 36, no. 3, pp. 571-582, May 2014, doi: 10.1007/s40430-013-01004.

[14] M. Farzaneh-Gord, M. Deymi-Dashtebayaz, and S. Hashemi-Marghzar, "Improving the efficiency of an industrial gas turbine by a novel inlet air cooling method," J. Energy Inst., vol. 82, no. 3, pp. 150-158, Sep. 2009, doi: 10.1179/014426009X12448168549949.

[15] A. Dinc, "An Application of a Computerized Data Acquisition System in Testing of an Auxiliary Power Unit,” Int. J. Sci. Eng. Res., vol. 6, no. 5, pp. 1057-
1064, 2015, [Online]. Available: http://www.ijser.org.

[16] A. Dinç, "Sizing of a Turboprop Engine Powered High Altitude Unmanned Aerial Vehicle and It's Propulsion System for an Assumed Mission Profile in Turkey," Int. J. Aviat. Sci. Technol., vol. vm01, no. is01, pp. 5-8, Sep. 2020, doi: 10.23890/IJAST.vm01is01.0101.

[17] A. Dinc, "Sizing of a turboprop unmanned air vehicle and its propulsion system," Isi Bilim. Ve Tek. Dergisi/ J. Therm. Sci. Technol., vol. 35, no. 2, pp. 53-62, 2015.

[18] A. Dinc, "Optimization of turboprop ESFC and NOx emissions for UAV sizing," Aircr. Eng. Aerosp. Technol., vol. 89, no. 3, pp. 375-383, May 2017, doi: 10.1108/AEAT-12-2015-0248.

[19] A. Dinc and Y. Gharbia, "Exergy analysis of a turboprop engine at different flight altitude and speeds using novel consideration," Int. J. Turbo Jet Engines, 2020, doi: 10.1515/tjeng-2020-0017.

[20] A. Dinc and I. Elbadawy, "Global warming potential optimization of a turbofan powered unmanned aerial vehicle during surveillance mission," Transp. Res. Part D Transp. Environ., vol. 85, Aug. 2020, doi: 10.1016/j.trd.2020.102472.

[21] Y. Şöhret, A. Dinç, and T. H. H. Karakoç, "Exergy analysis of a turbofan engine for an unmanned aerial vehicle during a surveillance mission," Energy, vol. 93, pp. 716-729, 2015, doi: 10.1016/j.energy.2015.09.081.

[22] J. Kurzke, GasTurb 11 User Manual. 2007.

[23] GE Energy, "LM6000-60 HZ Gas Turbine Generator Set," 2008.

[24] A. Dinc and Y. Gharbia, "Global Warming Potential Estimations of a Gas Turbine Engine and Effect of Selected Design Parameters," in Proceedings of the ASME 2020 International Mechanical Engineering Congress and Exposition Volume 8: Energy, Nov. 2020, vol. 8, pp. 1-7, doi: 10.1115/IMECE202023065 .

\section{Citation of this Article:}

Ali Dinc, Rani Taher, Javad Farrokhi Derakhshandeh, Mohamed Fayed, Ibrahim Elbadawy, Yousef Gharbia, "Performance Degradation of a 43 MW Class Gas Turbine Engine in Kuwait Climate" Published in International Research Journal of Innovations in Engineering and Technology - IRJIET, Volume 5, Issue 4, pp 108-113, April 2021. Article DOI https://doi.org/10.47001/IRJIET/2021.504016 